Permanent link for this document : https://doi.org/10.33367/tribakti.v31i2.1043

\title{
Living Hadis Penutupan Lapak Jual Beli Ketika Waktu Shalat di Kampung Madinah Desa Temboro Karas Magetan Jawa Timur
}

\author{
Khamim, ${ }^{1}$ Hizbulloh Hadziq ${ }^{2}$ \\ 1,2 Institut Agama Islam Negeri Kediri, Indonesia \\ ${ }^{1}$ khamimiainkediri.ac.id, ${ }^{2}$ hadziqiainkediri.ac.id
}

\begin{abstract}
One of the interesting phenomena in the "Kampung Madinah" in Temboro Karas Magetan is the tradition of closing shop when the prayer time. The urgency in this research is to review these practices and explain their correlation with the hadith or sunnah of the Messenger of Allah. The research is field research that limits the problem to the application of the value of the sunnah to the tradition of closing shop in the kampung Madinah. The approach used is the sociology of knowledge which implies that reality is socially constructed. The result is that the tradition of closing shop when prayer time is the process of conveying the understanding conveyed by the followers of Jamaah Tabligh through the study of the book Faḍail al-A'māl which is recited at both bayan and ta'lim. Thus the closing shop when the prayer time is the actualization of the understanding of fiqh inspired by the hadith about the superiority of prayer in congregation.
\end{abstract}

Keywords: closing shop, prayer time, and Living Hadis.

\begin{abstract}
Abstrak
Salah satu fenomena menarik di "kampung madinah" yang berada di Desa Temboro Karas Magetan adalah tradisi menutup lapak jual beli ketika adzan waktu shalat. Urgensi dalam penelitian adalah untuk mengulas praktik tersebut dan memaparkan korelasinya dengan hadis atau sunnah Rasulullah SAW. Penelitian ini berada dalam lingkup penelitian lapangan (field research) yang membatasi masalah pada penerapan nilai sunnah dalam tradisi menutup lapak jual beli ketika waktu shalat di kampung Madinah desa Temboro. Pendekatan yang digunakan adalah pendekatan sosiologi pengetahuan yang menyiratkan makna bahwa kenyataan itu dibangun secara sosial. Hasil penelitian ini menyimpulkan bahwa tradisi penutupan lapak jual beli ketika adzan waktu shalat fardlu merupakan penanaman konsep yang disampaikan secara berkesinambungan oleh para pengikut Jamaah Tabligh melalui pengajaran kitab Fadail al- $A$ 'māl yang dibacakan saat bayan maupun ta'lim. Dengan demikian praktik penutupan lapak jual beli ketika waktu shalat ini sebenarnya adalah aktualisasi dari pemahaman fiqih yang muncul dan terinisiasi oleh hadis tentang keutamaan shalat berjamaah.
\end{abstract}

Kata Kunci: Penutupan Lapak Jual Beli, Waktu Shalat, dan Living Hadis.

\section{Pendahuluan}

Fenomena Temboro Magetan dengan ajaran Jamaah Tablighnya telah memunculkan berbagai bentuk tradisi sosial keagamaan yang jarang diketemukan di Tribakti: Jurnal Pemikiran Keislaman Volume 31, Nomor 3, Juli 2020 
tempat lain. Salah satunya adalah tradisi penutupan lapak jual beli menjelang masuknya waktu shalat fardlu. Beberapa peneliti telah turut serta dalam mengungkap fakta unik di Temboro. Namun sejauh ini belum ada yang mengungkap tradisi penutupan lapak jual beli ketika shalat, terutama dalam lingkup kajian living hadis. Misalnya tesis yang ditulis oleh Fadhol Muhammad Luthfi Alwi dengan judul Peran Pondok Pesantren Terhadap Kegiatan Bisnis di Kampung Madinah desa Temboro Kecamatan Karas Kabupaten Magetan, Analisa Etika Bisnis. Melalui kajian etika bisnis, Fadhol hanya mengungkap histori munculnya brand kampung Madinah sebagai pengaruh keberadaan pesantren di Temboro. Sedangkan M. Yusuf melalui pendekatan teori gerakan sosial dalam disertasinya yang berjudul Jamaah Tabligh Temboro Magetan (Studi Gerakan Sosial Lokal Berorientasi Nilai)menyimpulkan bahwa Jamaah Tabligh merupakan tipe gerakan reformasi (islah) parsial, yaitu sebuah usaha untuk memperbaiki aspek-aspek tertentu dari kehidupan masyarakat.

Desa Temboro yang berada di wilayah Kecamatan Karas Magetan merupakan sebuah desa yang menjadi tempat perkembangan ajaran Jamaah Tabligh (JT) di Indonesia dengan pusat pengajarannya di Pondok Pesantren Al-Fatah. Di desa ini terdapat sebuah lokasi yang disebut kampung Madinah. Penyebutan terhadap salah satu dusun yang masyarakatnya berupaya meniru bentuk kehidupan di zaman Nabi SAW.

Salah satu fenomena menarik di kampung ini adalah adanya tradisi melakukan penutupan lapak jual beli di lapak jual beli, baik di pasar maupun pertokoan ketika masuk waktu shalat. Begitu adzan dikumandangkan maka seluruh pedagang yang ada di kampung tersebut segera menutup lapak jual belinya dan bersiap mengikuti shalat berjamaah. Penutupan lapak ini seolah sudah menjadi kesepakatan bersama seluruh warga kampung.

Tradisi ini tidak bisa dilepaskan dari keberadaan Pesantren Al-Fatah yang berada di desa tersebut. Misi pesantren dalam menyampaikan ajaran Islam melalui kegiatan khurüj, memperbaiki diri dan menegakkan perjalanan dakwah Rasulullah ${ }^{1}$ telah berhasil menciptakan tradisi yang khas di tengah masyarakat kampung Madinah. Sehingga dalam setiap kegiatannya mereka memfokuskan diri pada peningkatan keimanan dan amal-

1 Mundzier Suparta, Perubahan Orientasi Pondok Pesantren Salafiyah terhadap Perilaku Keagamaan Masyarakat. Jakarta: Asta Buana Sejahtera, 2009. H. 191, 203-204, dan 231-232; dan Zainal Arifin, Islam di Temboro Model Kepemimpinan dan Strategi Kebudayaan Jamaah Tabligh dalam Pembentukan Karakter. Yogyakarta: Program Studi MPI Fakultas Ilmu Tarbiyah dan Keguruan UIN Sunan Kalijaga Yogyakarta, 2017. H. 111-131 dan 134. 
amal saleh. ${ }^{2}$ Hal ini membuat kegiatan-kegiatan yang dilakukan oleh masyarakat Temboro tampak selaras dengan tujuan tersebut, karena mayoritas mereka adalah pengikut JT yang diajarkan oleh pesantren tersebut. Tradisi unik ini sangat menarik untuk diteliti guna melacak proses keterbentukannya dan menemukan korelasinya dengan sunnah Nabi Muhammad SAW. Sekaligus untuk menggambarkan model pemahaman masyarakat terhadap hadis dan perwujudannya dalam praktik. Oleh karena itu dalam penelitian ini peneliti mengajukan dua pertanyaan penelitian, pertaman, bagaimana masyarakat kampung Madinah melakukan penutupan lapak jual beli ketika memasuki waktu shalat? Kedua bagaimana tradisi penutupan lapak jual beli ketika waktu shalat di kampung Madinah itu diinisiasi dari sunnah Nabi SAW?

\section{Metode}

Target dalam penelitian ini adalah untuk mengungkap adanya praktik living hadis di balik tradisi penutupan lapak jual beli menjelang dikumandangkannya adzan shalat di kampung Madinah Temboro. Oleh karena itu pendekatan yang penulis gunakan adalah sosiologi pengetahuan yang dikembangkan oleh Peter L. Berger dan Thomas Luckmann. Keduanya memandang bahwa kenyataan itu dibangun secara sosial sedangkan sosiologi pengetahuan bertugas menganalisa terhadap proses terjadinya hal itu. Dalam hal ini tradisi penutupan lapak jual beli yang dianggap sebagai pengetahuan dalam bentuk "pengamalan sunnah nabi", namun bisa dipahami secara berbeda oleh orang lain sesuai dengan kadar penalarannya. Oleh karenanya "kenyataan/ realitas dan pengetahuan" di sini penting untuk diposisikan sebagai perhatian utama, sebab pengetahuan selalu dibentuk dalam konteks. ${ }^{3}$ Tradisi penutupan lapak jual beli ketika sholat dinilai sebagai satu fenomena riil dan mempunyai karakteristik. Praktiknya terbentuk sebagai realitas yang hadir dalam kesadaran individu (realitas yang bersifat subjektif). Wujudnya merupakan perpaduan adanya hubungan timbal balik antara realitas sosial yang bersifat objektif dengan pengetahuan yang bersifat subjektif. Menurut Berger hal ini didasarkan pada konsep dasar tentang tiga momen dialektis, yaitu eksternalisasi, objektivasi, dan internalisasi ${ }^{4}$

\footnotetext{
${ }^{2}$ Mundzier Suparta, Perubahan _, H.62.

${ }^{3}$ Zuly Qodir, Islam Liberal, Varian-varian Liberalisme di Indonesia. Jogjakarta: Lkis, 2010. H. 16

${ }^{4}$ Eksternalisasi adalah proses pembentukan pengetahuan latar belakang yang tersedia untuk dirinya serta untuk orang lain. Objektivikasi adalah proses meneruskan pengetahuan latar belakang tersebut kepada generasi berikutnya secara objektif. Internalisasi adalah proses yang menjadikan kenyataan sosial yang sudah menjadi kenyataan obyektif untuk ditanamkan ke dalam kesadaran, terutama pada anggota Tribakti: Jurnal Pemikiran Keislaman Volume 31, Nomor 2, Juli 2020
} 
Kajian penelitian ini bersifat teoritis dan empiris, sehingga metode pengumpulan data yang digunakan diantaranya adalah: Wawancara, untuk menggali data tentang proses dan kegiatan penutupan lapak jual beli ketika waktu shalat. Observasi, yang dilakukan dengan cara mengamati secara langsung aktifitas pedagang dalam menutup lapak jual beli mereka beserta pelaksanaan shalat berjamaah. Dan dokumentasi untuk mengumpulkan data profil kampung Madinah yang menjadi pusat kegiatan pedagang yang melakukan penutupan lapak jual beli.

\section{Hasil dan Pembahasan \\ Kampung Madinah}

Kampung Madinah adalah penyebutan yang dilakukan masyarakat terhadap sebagian wilayah padukuhan yang ada di desa Temboro. Penyebutan ini tidak terlepas dari fenomena unik yang dijumpai di kampung tersebut. Suasananya lebih menunjukkan nuansa khas pesantren dari pada sebuah perkampungan. Penampilan masyarakatnya berbeda dengan desa-desa lain pada umumnya. Yang perempuan kebanyakan memakai kerudung, bahkan ada juga yang menutup seluruh tubuhnya dengan pakaian berwarna gelap dan menggunakan burka. Hanya sebagian kecil saja yang tampak tidak berkerudung (berhijab). Sedangkan yang laki-laki sebagian besar memakai penutup kepala, berjubah atau memakai baju gamis dan celana khas yang panjangnya di atas mata kaki. Sebagian yang lain memakai kaos, namun masih tetap memakai penutup kepala (kopyah). Selain dari sisi penampilan, mereka juga sangat memperhatikan aspek ibadah. Ketika tiba waktu shalat para laki-laki berduyun-duyun ke masjid dan aktifitas dihentikan sementara sampai selesai shalat. ${ }^{5}$

\section{Pesantren Al-Fatah Temboro}

Pondok Pesantren Al-Fatah adalah sebuah pesantren yang terletak di Temboro yang didirikan pada tahun 1939 oleh KH. Shidiq. Pondok pesantren ini dulunya menjadi basis pendidikan ormas NU masyarakat Magetan dan sekitarnya, namun belakangan berubah menjadi pusat pengembangan ajaran dakwah Jamaah Tabligh tepatnya ketika

\footnotetext{
masyarakat baru, dalam kontek proses sosialisasi. Lihat Bagja Waluya, Sosiologi: Menyelami Fenomena Sosial di Masyarakat, Bandung:Setia Purna Inves. 2004. H.43

${ }^{5}$ Azzahro Amalia, Strukt ur Sosial Keagamaan Jamaah Tabligh di desa Temboro Kecamatan Karas Kabupaten Magetan, Antropologi Fisip Universitas Airlangga Surabaya. H. 3
} 
berada di bawah kepemimpinan Kiyai Haji Mahmud dan Kiyai Haji Uzairon. ${ }^{6}$ Jamaah Tabligh merupakan komunitas dari kaum muslimin yang bergerak di bidang dakwah yang hampir semua aktivitas kesehariannya selalu berpedoman pada hadis atau sunnah. Bagi mereka, suatu dakwah akan berhasil jika mengacu kepada tiga bentuk sunnah yang disandarkan pada Nabi SAW, yaitu sunnah surah, sunnah sirah, dan sunnah sarirah. ${ }^{7}$

Keterikatan pesantren dengan dakwah Jamaah Tabligh ini bermula dari adanya kunjungan seorang ulama dari Pakistan yang bernama Abdussobur beserta rombongan pada tahun $1984 .^{8}$ Kedatangan mereka dalam rangka menjalankan tugas dakwah yang berikan oleh Maulana In'amul Hasan, pemimpin tertinggi Jamaah Tabligh di India. Kunjungan tersebut berlanjut dengan adanya pertemuan secara langsung antara pengasuh pesantren Al Fatah dengan Maulana In'amul Hasan di India. Ajaran ini kemudian diterima oleh pengasuh pesantren dan didakwahkan secara intens kepada masyarakat Temboro. Dakwah tersebut dilakukan dengan cara mengunjungi masyarakat serta mengajak mereka agar hidup dalam ketaatan kepada Allah SWT dengan menjalankan amal-amal keutamaan.

Jamaah Tabligh memiliki konsep dakwah yang disebut khurūj. Tujuan yang diperjuangkan dalam dakwah ini adalah membangkitkan semangat keberagamaan umat Islam, menghidupkan spiritualitas dalam diri dan setiap kehidupan kaum muslimin. ${ }^{9}$ Khurūj merupakan bentuk ikhtiar edukasi dalam membimbing dan membawa masyarakat supaya sadar iman dan agama, mengamalkan dan memperjuangkannya hingga tercipta masyarakat muslim yang berkarakter Islami. ${ }^{10}$ Pelaksanaan khurüj biasanya dilakukan dalam tiga tahap, yaitu 3 hari dalam sebulan, 40 hari dalam setahun atau 4 bulan sekali dalam seumur hidup. Bilangan tersebut merupakan hitungan 10\% dari waktu atau umur manusia yang hendaknya diinfakkan untuk kepentingan dakwah.

6 Muhammad Luthvi Al Hasyimi, "Dampak Faham Keagamaan Jamaah Tablig Terhadap Perubahan Sistem Pendidikan Di Pondok Pesantren Al Fatah Desa Temboro Kecamatan Karas Kabupaten Magetan”. Jurnal Intelektual(2017) Vol. 7, No. 1: 100

7 Muhammad Zaki, Metode Pemahaman Dan Pengamalan Hadits Jamaah Tabligh, Jurnal Pengembangan Masyarakat Islam (Agustus 2015) Vol. 8, No. 2, H.104

${ }^{8}$ Samsul Munir, Pluralisme Madzhab Dakwah Jamaah Tabligh di Kampung Madinah, (Yogyakarta: Pustaka Ilmu, 2015), h. 139

${ }^{9}$ Edi Amin, "Dakwah Raḥmatan li al-'Ālamīn Jamā'ah Tabligh Rahmatan Lil Alamin Jamaah Tabligh di Kota Jambi”, Jurnal Komunikasi Islam, (Juni 2012), vol. 02. No. 01. h. 35.

${ }^{10}$ Moh. Yusuf, Gerakan Khurūj fi Sabīillāh Sebagai Upaya Edukasi Membentuk Karakter Masyarakat: Studi Kasus Dakwah Jamā'ah Tabligh Jamaah Tabligh Temboro Magetan melalui Pendekatan Framing, Jurnal Kontemplasi, (Agustus, 2017) Vol. 05 No. 01. H. 163

Tribakti: Jurnal Pemikiran Keislaman

Volume 31, Nomor 2, Juli 2020 
Biasanya mereka berdakwah secara berkelompok yang terdiri dari kurang lebih 5-10 orang dengan biaya dari kantong sendiri. ${ }^{11}$

Pengaruh dakwah ini telah berhasil membentuk perilaku masyarakat dalam meniru pola kehidupan di zaman rasulullah SAW yang dijumpai dari beberapa hadis untuk diterapkan dalam kehidupan keseharian. Dari sinilah terbentuk sebuah tradisi yang khas di masyarakat Temboro, salah satunya adalah tradisi penutupan lapak jual beli ketika waktu shalat.

Ketika adzan dikumandangkan, masyarakat bergegas mempersiapkan diri mengikuti shalat berjamaah di masjid, tak terkecuali para pedagang di pasar maupun pertokoan. Suasana pasar atau jalanan yang semula ramai berangsur-angsur menjadi lengang. Aktivitas warga tidak begitu terlihat kecuali mereka yang berangkat ke masjid, ada yang naik sepeda motor dan ada juga yang berjalan kaki.

Misi Jamaah Tabligh dalam menghidupkan masjid dengan kegiatan shalat berjamaah dapat dijumpai dasarnya dalam kitab Faḍāilu al-a'māl yang ditulis oleh alKandahlawi. Dalam muqaddimah kitab yang menjadi pegangan Jamaah Tabligh ini alKandahlawi menyatakan keprihatinannya yang mendalam atas kelalaian sebagian umat Islam terhadap ajaran sendiri. Bencana kelalaian ini hampir merata di kalangan umat Islam. Banyak yang mulai tidak mempedulikan perintah agama termasuk perintah melakukan shalat. ${ }^{12}$

Mengenai sikap kebanyakan orang terhadap shalat, Al-Kandahlawi memetakannya dalam tiga kelompok. Kelompok pertama adalah mereka yang sama sekali tidak mempunyai kepedulian terhadap kewajiban shalat walaupun hanya sekedar memikirkan saja. Kelompok kedua adalah mereka yang mau melaksanakan shalat tapi enggan melaksanakannya dengan berjamaah. Sedangkan kelompok ketiga adalah mereka yang mau melaksanakan shalat secara berjamaah namun tidak memperhatikan syarat-syarat dan adab dalam menjalankan shalat. ${ }^{13}$

${ }^{11}$ Wawancara dengan Ridwan pada tanggal 28 Agustus 2019 di lokasi pasar Temboro

${ }^{12} \mathrm{Kitab}$ yang ditulis oleh Kandahlawi diberi nama Faḍil al- $A$ 'mal yang berisi hadis-hadis Nabi yang menerangkan tentang amal-amal yang diutamakan karena memiliki fadilah. Kitab inilah yang menjadi pegangan Jamaah Tabligh dan sering dibacakan dalam kegiatan bayan maupun ta'lim,

${ }^{13}$ Muhammad Zakariya ibn Muhammad Yahya al-Kandahlawi, Majmū'atu al-Rasāil fì Faụāili alA'māl wa al-Akhlāq. India: al-Maktabah al-Yahyawiyyah.2011. H.16 


\section{Penutupan Lapak Jual Beli Ketika Waktu Shalat di Kampung Madinah}

Dari hasil observasi dan wawancara, ditemukan bahwa aktivitas penutupan lapak jual beli ketika waktu shalat telah menjadi kegiatan yang disepakati dan dilakukan secara berulang sehingga menjadi satu budaya di kampung Madinah. Menurut J.J Hoenigman kebudayaan dapat ditampakkan dalam tiga wujud: ideas (gagasan), activities (aktivitas) dan artifacts (artefak). ${ }^{14}$ Sehingga activities (aktivitas) di sini adalah wujud kegiatan penutupan lapak jual beli di saat-saat waktu shalat di kampung Madinah. Kebiasaan ini berlangsung sebagai ritual yang berulang secara periodik dalam hubungan antar masyarakat Temboro dengan komunitas pesantren secara teknis, sosiokultural, rekreasional dan religius.

Wujud aktivitas ini terkadang dibahasakan dengan istilah sistem sosial. Yaitu sebuah sistem yang terdiri dari aktivitas-aktivitas manusia yang saling berinteraksi, mengadakan kontak, serta bergaul dengan manusia lainnya menurut pola-pola tertentu berdasarkan adat tata kelakuan. Sifatnya konkret, terjadi dalam kehidupan sehari-hari, dan dapat diamati serta didokumentasikan. ${ }^{15}$

Sebagai entitas budaya, tradisi penutupan lapak jual beli ketika waktu shalat di kampung Madinah tidak terjadi begitu saja, melainkan muncul sebagai respon dari beberapa faktor yang berpengaruh secara signifikan terhadap terbentuknya kebiasaan tesebut. Faktor-faktor tersebut adalah faktor geografis, historis dan faktor interaksi.

Pengaruh faktor geografis dapat di amati dari lokasi kampung Madinah yang berada di jalan utama yang menghubungkan desa Temboro dengan daerah-daerah lain di sekitarnya. Kedekatan lokasinya dengan pesantren Al-Fatah yang mengajarkan ajaran Jamaah Tabligh juga memberikan pengaruh terhadap dinamika kehidupan kampung tersebut, baik secara ekonomi maupun keagamaan. Posisi geografis yang demikian mendukung terciptanya situasi interaksional antara penduduknya dengan para santri pondok maupun para pendatang dari luar daerah. Bentuk-bentuk interaksi ini secara nyata telah mampu melepaskan sekat yang ada di antara mereka. Hal ini dapat dilihat ketika mereka melakukan transaksi jual beli di pasar atau pertokoan di seputar dusun Temboro. Bahkan interaksi ini juga merambah ke wilayah religi yang dimanifestasikan ke dalam bentuk-bentuk kegiatan keagamaan seperti ta'lim, shalat berjamaah ataupun

\footnotetext{
${ }^{14}$ Abdurrahman Misno Bambang Prawiro, Pesona Budaya Sunda: Etnografi Kampung Naga, Sleman: Budi Utama, 2019.H.12

${ }^{15}$ Wikipedia Ensiklopedia Bebas,Budaya," dalam https://id.wikipedia.org/wiki/Budaya (diakses pada tanggal 02 Oktober 2019 pada pukul 20.28)

Tribakti: Jurnal Pemikiran Keislaman

Volume 31, Nomor 2, Juli 2020
} 
bayan (pengajian setelah shalat jamaah), dimana masing-masing turut terlibat menjadi peserta sehingga menjadi sebuah komunitas yang menyatu.

Dari telaah historis, tradisi penutupan lapak jual beli tersebut menunjukkan adanya relasi sejarah dengan ajaran dakwah Jamaah Tabligh yang masuk ke desa Temboro sekitar tahun 80 an. Kebiasaan yang sebelumnya bukan menjadi bagian dari kehidupan masyarakat Temboro, kini telah menjadi perilaku khas dan identitas yang melekat pada masyarakat Temboro. Relasi sejarah ini diawali dari dakwah yang dilakukan secara intens oleh pengasuh pesantren Al-Fatah dengan cara mendatangi secara langsung perumahan para warga Temboro untuk mengajak mereka hidup dalam ketaatan kepada Allah SWT dan menjalankan amal-amal keutamaan, termasuk menghidupkan masjid dengan kegiatan berjamaah.

Selain hal itu, tradisi ini dapat juga dibaca sebagai pengaruh adanya interaksi sosial antar manusia. Yaitu keterlibatan pengelola (santri dan pengasuh) pesantren AlFatah dalam menyebarkan dakwah Jamaah Tabligh. Interaksi itu terjadi ketika para pengikut Jamaah Tabligh melakukan dakwah khuruj di tengah-tengah masyarakat secara terus-menerus dan berkelanjutan. Misalnya dalam kegiatan ta'lim dan bayan. Interaksi ini menjadi media transfer pengetahuan sehingga memunculkan kreasi penutupan lapak jual beli sebagai menifestasi dari memahami perintah penggiatan shalat secara berjamaah.

Berdasarkan sosiologi pengetahuan, tradisi penutupan lapak jual beli ketika waktu shalat ini dapat dihubungkan dengan rintisan dakwah pengasuh pesantren Al-Fatah yang berupaya menyebarkan ajaran dakwah Jamaah Tabligh kepada masyarakat Temboro, sehingga secara berangsur mereka dapat menerima ajakan dakwah tersebut. Dakwah yang dilakukan secara terus-menerus ini akhirnya membawa perubahan pola fikir dan perilaku masyarakat Temboro untuk menyesuaikan atau bahkan mengikuti dakwah tersebut.

Melalui fenomena perubahan perilaku dan pola pikir masyarakat Temboro ini kita bisa melihat terjadinya sebuah proses eksternalisasi. Proses ini ditunjukkan ketika pengasuh pesantren Al-Fatah menyampaikan dakwah ajakan pemakmuran masjid dengan kegiatan shalat berjamaah. Terjadinya eksternalisasi ketika kegiatan shalat berjamaah dipahami bentuk praktiknya dengan melakukan penutupan lapak jual beli yang dihadirkan ke dalam realitas sosial. Pemaknaan ini wajar, karena ketika sebuah teks hadir ke tengah masyarakat, maka ia telah menjadi milik publik. Publik pun akan 
memberikan apresiasi dan pemahaman sesuai dengan kadar intelektualitas yang mereka miliki. ${ }^{16}$

Sehingga pada tahap ini terjadi pemaknaan subyektif atau ekspresif yang muncul dari pengikut ajaran dakwah Jamaah Tabligh. Dimana mereka menempatkan fạāilu ala'mālyang hanya bernilai sunnah pada sebuah tempat yang seolah wajib dilaksanakan. ${ }^{17}$ Pemaknaan perintah shalat berjamaah dengan penutupan lapak jual beli ini secara tidak langsung telah mempengaruhi psikologis masyarakat Temboro untuk mewajibkan diri menutup lapak jualnya ketika tiba waktu shalat.

Sebenarnya pemaknaan yang demikian adalah pemahaman subyektif yang terkadang berbeda dengan pemahaman lain. Terlebih dalam tinjauan fikih, hukum shalat berjamaah merupakan persoalan ijtihad yang masih diperselisihkan hukumnya. Sehingga jika kemudian terjadi pemaknaan yang seragam maka dapat dikatakan bahwa pemahaman tersebut diproduksi oleh semua yang terlibat khususnya para perintis ajaran dakwah jamaah Tabligh. Pemaknaan ini lalu ditransformasikan ke generasi-generasi berikutnya sehingga terbentuk pola interaksi yang berkelanjutan di Temboro.

Proses kedua adalah tahap obyektivikasi sebagai kelanjutan dari aplikasi makna ekspresif atau proses. Yaitu ketika pemaknaan yang semula bersifat subyektif dan individual diwujudkan menjadi suatu konsep yang disepakati bersama. Awalnya, penutupan lapak jual beli ketika waktu shalat maktubah adalah amaliah yang umumnya dilakukan secara individu berdasarkan kesadaran diri para pelakunya. Namun kemudian dalam tahap ini, amaliah tersebut diorganisir secara sistematis untuk diproyeksikan menjadi kegiatan kolektif (dilakukan secara berjamaah).

Dalam upayanya, warga yang tidak tampak mengikuti jamaah di masjid dikunjungi (dijaulahi) ke rumahnya, diajak mengobrol secara baik-baik dan akhirnya diajak untuk mengikuti shalat berjamaah. Metode pendekatan yang demikian ini membuat masyarakat Temboro bisa menerima dan bahkan turut mendukungnya sehingga terbentuklah suatu budaya yang disepakati dan dijalani bersama. Dari obyektivikasi inilah penutupan lapak jual beli menjadi makna aplikatif yang disepakati masyarakat ketika tiba waktu shalat. Inilah yang disebut dengan makna obyektif yang diwujudkan

${ }^{16}$ Didi Junaedi, Memahami Teks, Melahirkan Konteks: Menelisik Interpretasi Ideologis Jamaah Tabligh, Journal of Qur'ān and Hadith Studies (2017). Vol. 2, No. 1. H. 2

${ }^{17}$ Amal utama dalam kasus ini adalah shalat berjamaah yang mana para ulama berbeda pendapat mengenai hukum shalat berjamaah, apakah wajib atau hanya mustahab dan sunnah muakkadah atau menjadi syarat sah.

Tribakti: Jurnal Pemikiran Keislaman

Volume 31, Nomor 2, Juli 2020 
dalam kesepakatan bersama untuk menutup lapak jual beli di saat masuk waktu shalat wajib. Makna inilah yang pada akhirnya berlaku secara universal menjadi kegiatan yang dilakukan secara kolektif oleh masyarakat kampung Madinah.

Proses terakhir adalah proses internalisasi, yaitu proses yang dialami manusia untuk mengambil alih dirinya. Tahap ini adalah tahap dimana manusia mensosialisasikan apa yang ia pikirkan ke dalam dunianya, yaitu dunia sosial hingga terbentuk interaksi sosial. Obyektivikasi dalam budaya masyarakat pasar Temboro bisa dilihat dari adanya kegiatan dakwah baik ta'lim maupun bayan yang dilaksanakan secara terus menerus untuk menyampaikan pentingnya shalat berjamaah. Adanya interaksi sosial sebagai akhir proses pengetahuan yang ditransfer merupakan ciri adanya nilai internal dalam budaya masyarakat kampung Madinah yang berusaha dipahami dan diaplikasikan ke dalam lingkup sosial.

Dalam proses ini, internalisasi adalah proses menjadikan budaya penutupan lapak jual beli yang telah menjadi kenyataan obyektif, menjadi suatu kebenaran yang ditanamkan ke dalam kesadaran pribadi, terutama untuk dilanjutkan kepada generasigenerasi berikutnya atau kepada anggota masyarakat baru. Dengan demikian ketiga proses yang menjadi dasar hubungan masyarakat Temboro dengan lingkungan sosialnya (eksternalisasi-objektivikasi-internalisasi) tidak hanya berhenti sampai disitu saja. Ia akan terus berjalan seiring waktu seperti mata rantai yang tidak terputus. Proses sosialisasi tidak pernah berhenti. Sepanjang ekspresi dakwah Jamaah Tabligh ini dilakukan maka proses sosial akan terus berlanjut. Melalui proses sosial yang berkelanjutan ini pada akhirnya semua orang yang terlibat di dalamnya memiliki pemahaman dan tujuan yang sama, yaitu bagaimana mengaplikasikan keutamaan melaksanakan shalat berjamaah ketika sedang melakukan kegiatan jual beli.

Jika dilihat dalam bingkai sosiologi, maka budaya masyarakat Temboro merupakan bentuk transfer pengetahuan yang dilakukan secara terus menerus dalam interaksi sosial. Alur proses terbentuknya budaya tersebut dapat dijelaskan dalam gambar berikut: 


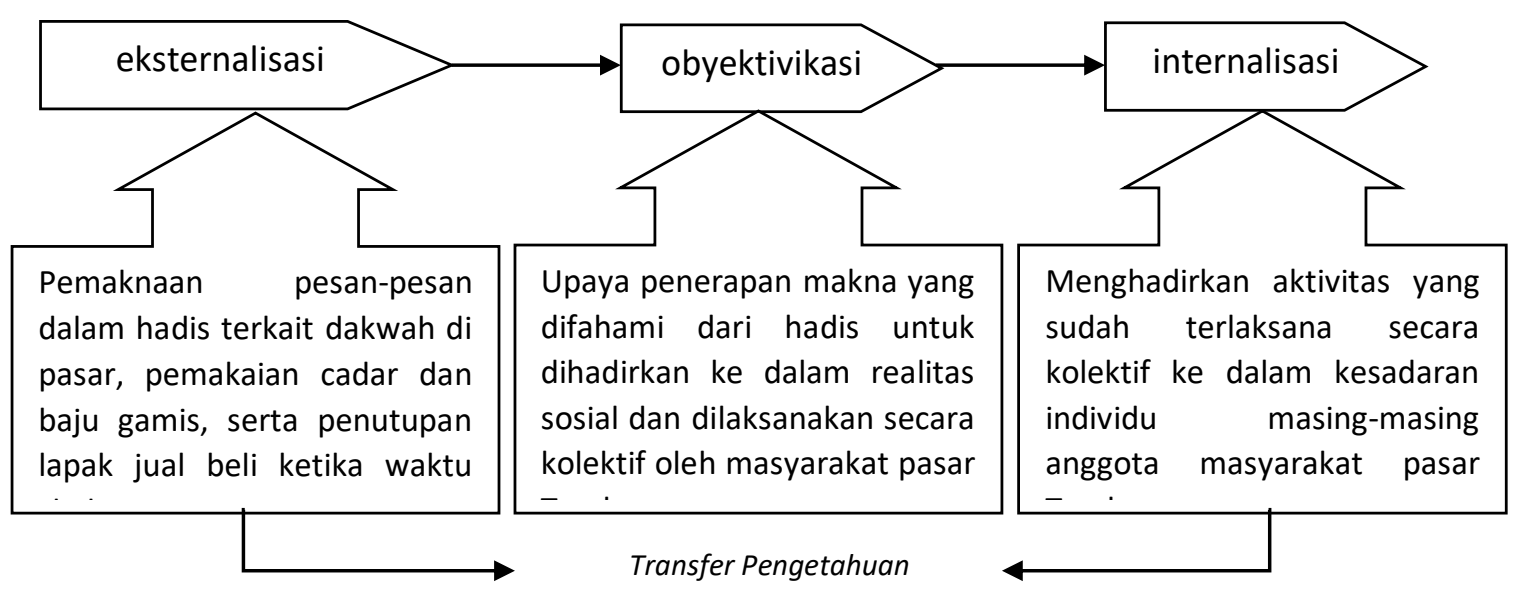

Gambar 1: Alur terbentuknya tradisi penutupan lapak jual beli di Temboro

\section{Inisiasi Hadis pada Tradisi Penutupan Lapak Jual Beli Ketika Waktu Shalat di Kampung Madinah}

Kebiasaan masyarakat kampung Madinah Temboro dalam menutup lapak jual beli saat waktu shalat merupakan praktik yang diilhami dari hadis yang menerangkan pentingnya shalat dan keutamaan melakukannya secara berjamaah. Hal ini karena mereka menerima pengetahuan tentang penutupan lapak jual beli ketika waktu shalat melalui pengajaran kitab hadis yang menjadi pegangan Jamaah Tabligh yaitu kitab fadail al-A'māl yang dibacakan saat bayan maupun ta'lim. Dalam bab risalah shalat yang tertulis dalam kitab tersebut, keutamaan dibahas secara luas dalam sub bab tersendiri. ${ }^{18}$ Hadis yang serupa juga diriwayatkan oleh Ibnu Majah. ${ }^{19}$

Pemahaman tersebut juga diperkuat dengan fakta sejarah generasi salaf pada zaman dahulu yang terbiasa melakukan penutupan lapak jual beli untuk melakukan shalat berjamaah, seperti athar dari Sālim dan Ibnu Mas'ud berikut ini. Berita ini telah didokumentasikan dengan baik dalam beberapa riwayat, di antaranya adalah athar Sālim Ibn 'Abdillāah yang diriwayatkan oleh Ibnu Kathir dalam tafsirnya, ${ }^{20}$ dan juga athar riwayat Ibnu Mas'ud yang diriwayatkan oleh al-Ṭabary. ${ }^{21}$ :

Memahami hadis yang menerangkan keutamaan shalat berjamaah dengan dengan pemaknaan yang demikian dapat dipahami sebagai bentuk pelestarian pemahaman hadis

${ }^{18}$ Muhammad Zakariya ibn Muhammad Yahya al-Kandahlawi, Majmū'atu al-Rasāil fi Faḍàili alA'māl wa al-Akhlāq. India: al-Maktabah al-Yahyawiyyah.2011. H.65-75

${ }^{19}$ Abu Abdillah Muhammad ibn Yazid Al-Quzwini, Sunan Ibn Majah, bāb Șalātu fí jamāăatin juz 1 (Kairo: Maktabat Dar al-Ihyā, tth). H. 260

${ }^{20}$ Lihat dalam Imāduddin Abi al-Fidā Ismāil ibnu Kathìr, Tafsir Ibnu Kathir Juz 10, Jizah: Muassasah Qurțubah. Tth. H. 252

${ }^{21}$ Lihat dalam Abu Ja'far Muhammad ibn Jarir al-Ṭabary, Tafsìru al-Ṭabary, Jämi'u al-Bayān 'an Ta'wīli Āyi al-Qur'ān juz 12, Kairo: Hajr. 2001. H. 321-322

Tribakti: Jurnal Pemikiran Keislaman

Volume 31, Nomor 2, Juli 2020 
dalam pemaknaan yang sudah jadi. Sehingga makna inilah yang selalu diajarkan ketika menyampaikan hadis-hadis tentang shalat berjamaah. Al-Kandahlawi menerangkan bahwa yang dimaksud dengan penegakan kalimah Allah SWT (li takūna kalimat Allāi hiya al-'Ulya) dan tidak adanya agama di bumi yang mengungguli agama Islam tidak bisa digambarkan konsepnya kecuali dalam kebersamaan umat Islam, apapun kedudukannya dalam satu syiarnya, yaitu pelaksanaan shalat jum'at dan shalat berjamaah. $^{22}$

Secara redaksional sebenarnya hadis-hadis tentang keutamaan berjamaah tersebut tidak secara langsung bermakna harus menutup lapak jual beli ketika masuk waktu shalat. Artinya, masih sangat terbuka untuk dimaknai secara berbeda sesuai dengan nalar ijtihad bagi yang memahaminya. Karena shalat berjamaah dapat dilakukan oleh siapapun dan di manapun asal memenuhi persyaratannya. Sehingga penyeragaman praktiknya dalam satu bentuk penutupan lapak jual beli merupakan pengupayaan subyektivitas makna ke ranah realitas masyarakat secara luas.

Dalam kajian fikih, hukum kewajiban shalat berjamaah masih diperselisihkan oleh ulama. Muhammad Jawad menampilkan beberapa pandangan madzhab fikih mengenai hukum shalat berjamaah. Dalam pandangan madzhab Hambali, shalat berjamaah itu hukumnya wajib atas setiap individu yang mampu melaksanakannya. Hanya saja bila dikerjakan sendirian maka hukumnya tetap sah namun pelakunya berdosa. Sedangkan dalam madzhab Imamiyah, Hanafiyah, dan sebagian besar ulama Syafiiyah, hukum shalat berjamaah itu tidak wajib, melainkan hanya sunnah muakkadah saja. Adapun menurut Madzhab Imamiyah, kewajiban berjamaah itu hanya berlaku dalam shalat fardlu dan tidak berlaku dalam shalat sunnah kecuali shalat istisqa dan shalat dua hari raya saja. Hal ini berbeda dengan pendapat empat madzhab lainnya mengatakan perintah berjamaah itu berlaku secara mutlak, baik dalam shalat fardu maupun shalat sunnah. ${ }^{23}$

Dalam analisa Ibnu Rusyd, perbedaan pandangan mengenai hukum shalat berjamaah tersebut didasarkan pada perbedaan pandangan ulama dalam memahami hadis yang secara lahirnya tampak bertentangan. Hadis yang satu menunjukkan bahwa shalat jamaah bukan merupakan suatu kewajiban. Namun hanya bersifat keutamaan (kesempurnaan) yang apabila dilakukan akan melebihi pahala shalat yang dilakukan

${ }^{22}$ Muhammad Zakariya, Majmū'atu_ , H. 75

${ }^{23}$ Muhammad Jawad Mughniyah, Fiqih Lima Madzhab, Ja'fari, Hanafi, Maliki, Shafi'i, Hambali. Masykur, Afif Muhammad dan Idrus al-Kaff. Jakarta: Lentera. 2011. H. 122 
sendirian dengan selisih dua puluh derajat. Artinya shalat yang dilakukan sendirian sudah dihukumi sah, hanya saja pahalanya lebih sedikit. ${ }^{24}$ Sedangkan hadis yang kedua seolah mewajibkan pelaksanaan shalat berjamaah. ${ }^{25}$ Dengan adanya pertentangan makna hadis yang demikian itu akhirnya fuqaha menyimpulkan hukum yang berbeda mengenai hukum berjamaah. Ibnu Rusyd mengatakan bahwa masing-masing kelompok ketika menanggapi hadis yang digunakan sebagai hujjah kelompok lainnya, maka ia membelokkan makna hadis tersebut kepada makna yang sesuai pendapatnya. ${ }^{26}$

Namun penyeragaman pemahaman ini dapat diterima karena motivasinya adalah mengaplikasikan amaliah yang lebih utama untuk dilakukan. Karena fạ̄àil al-a’māl merupakan salah satu pilihan untuk melaksanakan satu makna yang mengandung fadiilah di antara makna-makna lain. Terlebih ulama telah sepakat mengenai keutamaan melakukan shalat berjamaah terlepas dari perbedaan pandangan mereka mengenai kewajibannya. Aplikasi makna hadis yang demikian ini sejalan dengan prinsip Jamaah Tabligh yang tidak membuka ruang untuk memperbincangkan masalah khilafiyah. Sehingga pemilihan salah satu makna yang paling utama dan disepakati oleh mayoritas ulama untuk diaplikasikan menjadi pilihan terbaik yang bisa menghindarkan dari perdebatan.

Penyeragaman waktu berjamaah ini juga juga berdasarkan pembagian shalat wajib/ Maktūbah ke dalam lima waktu dalam sehari semalam. Walaupun belum secara detail, ketentuan mengenai waktu shalat telah disinggung dalam al-Quran. Mustafa mengutip perkataan al-Qurțubi dalam menafsiri ayat 103 surat an-Nisa, bahwa makna kitāban Mawqūtan dalam ayat tersebut adalah ditentukan waktunya serta diwajibkan. Sedangkan Zaid Ibn Aslam mengatakan bahwa mawqūtan bermakna munajjam yakni dilakukan secara bertahap pada waktunya. Menurut ahli bahasa, kata ini bermakna diwajibkan pada waktu yang sudah tertentu. ${ }^{27}$ Dari beberapa penafsiran tersebut dapat disimpulkan adanya keseragaman para ahli tafsir dalam memahami adanya waktu-waktu tertentu yang ditetapkan sebagai waktu melaksanakan shalat. Dalam hadis, perincian

\footnotetext{
${ }^{24}$ Lihat dalam Malik ibn Anas, Al-Muwaththa' Riwāyatu Yahya ibn Yahya Juz 1, Beirut: Dār alGharb al-Islāmy.1997. H.188

${ }^{25}$ Lihat dalam Ahmad Ibn Muhammad Ibn Hanbal, Musnad__,H. 243

${ }^{26}$ Ibnu Rusyd al-Qurthuby, Sharh Bidāyatu al-Mujtahid wa Nihāyatu al-Maqāșid, Kairo: Dār alSalām.1995. H. 331-333

${ }^{27}$ Musțafa al-‘Adwa, Yawaqit al-Falāh fi Mawāqìt al-Shalāh. Ṭaif: Maktabat al-Bayan. 1988. H. 910
}

Tribakti: Jurnal Pemikiran Keislaman Volume 31, Nomor 2, Juli 2020 
waktu shalat secara lebih detail dapat dijumpai dalam hadis yang diriwayatkan oleh Imam Ahmad Ibn Hanbal di dalam kitab Musnadnya. ${ }^{28}$

Dengan beberapa dalil tersebut, maka para ulama fiqih dari kalangan mutaqaddimin menyepakati bahwa shalat maktübah hanya boleh dilaksanakan dalam batasan waktu-waktu tertentu sebagaimana ditunjukkan dalam hadis Ahmad Ibn Hanbal. Melihat ketersediaan waktu shalat pertama dan dimulainya shalat yang berikutnya maka dapat disimpulkan bahwa dengan berakhirnya waktu shalat yang pertama akan secara otomatis memasuki waktu shalat berikutnya, kecuali shalat subuh menuju shalat dzuhur. ${ }^{29}$ Hal ini berdasarkan hadis riwayat Qatadah yang diriwayatkan oleh Imam Muslim. ${ }^{30}$

\section{Kesimpulan}

Terbentuknya tradisi penutupan lapak jual beli yang dilakukan oleh masyarakat kampung Madinah Temboro menjelang masuknya waktu shalat wajib, tidak terlepas dari beberapa realitas sosial yang melingkupinya. Dalam sosiologi pengetahuan, realitas tersebut terjabar dalam tiga tahap, eksternalisasi, obyektivikasi dan internalisasi. Eksternalisasi adalah proses transfer pengetahuan yang diperankan oleh Jamaah Tabligh dalam dakwahnya. Pemaknaan terhadap hadis-hadis mengenai shalat berjamaah disampaikan ke masyarakat dalam pemahaman yang sedemikian rupa tanpa membuka celah adanya pemahaman lain. Sebab pemahaman yang disampaikan merupakan pemahaman yang telah disepakati oleh ulama (mahall al-ittifãq). Tahap objektivikasi terlihat dalam kegiatan dakwah yang disampaikan dalam kegiatan ta'lim, bayan maupun ketika melakukan khurüj. Dalam kegiatan dakwah ini terdapat semacam penanaman doktrin-doktrin ajaran Jamaah Tabligh, terutama yang berkaitan dengan kegiatan pemakmuran masjid dengan shalat berjamaah. Tahap terakhir adalah internalisasi, ketika pengetahuan itu sudah menjadi bagian setiap individu masyarakat, maka mereka dengan tanpa ada paksaan akan melaksanakannya berdasar kesadaran pribadi. Ketika komunitas ini melaksanakannya secara bersama-sama maka terbentuklah tradisi yang menjadi cerminan khas masyarakat tersebut.

\footnotetext{
${ }^{28}$ Lihat dalam Ahmad Ibn Muhammad Ibn Hanbal, Al-Musnad Juz 11. Kairo: Dār al-Hadith.1995. H. 408

${ }^{29}$ Wahbah al-Zuhayli, al-Fiqh al-Islami wa Adillatuhu. Beirut: Dar al-Fikr.1984. H. 506-511

${ }^{30}$ Lihat dalam Abu al-Husain Muslim ibn al-Hajjaj ibn Muslim al-Qushairi, Kitābu al-Masājid wa Mawạ̣̈i' al-salāt juz 3, H. 276 
Tradisi penutupan lapak jual beli merupakan praktik yang diinisiasi dari keberadaan hadis-hadis yang membicarakan keutamaan shalat berjamaah. Hadis-hadis tersebut sebenarnya dapat dijumpai dalam kitab-kitab sumber pokok, semisal kitabkitab hadis yang tergabung dalam kutub al-sittah. Adapun kitab fadlail al-a'mal sejatinya merupakan kitab penjabaran (sharh) hadis. Hanya saja yang diutamakan di dalamnya adalah hadis-hadis yang membicarakan tentang fadlilah-fadlilah melaksanakan amal-amal keutamaan. Shalat berjamaah merupakan salah satu di antara amal keutamaan yang menjadi bagian penting yang disampaikan dalam kitab tersebut. Bagian ini menjadi substansi dakwah jamaah tabligh dalam kegiatan memakmurkan masjid. Kitab hadis inilah yang selanjutnya diajarkan dalam setiap kegiatan-kegiatan dakwah Jama'ah Tabligh di semua tingkatannya, baik ta'lim, bayan maupun mahillah dan menjadi referensi penutupan lapak jual beli ketika masuk waktu shalat wajib.

\section{Daftar Pustaka}

al-‘Adwa, Musțafa. Yawaqit al-Falāh fi Mawāqīt al-Shalāh. Taif: Maktabat al-Bayan. 1988.

al-Kandahlawi, Muhammad Zakariya ibn Muhammad Yahya. Majmū'atu al-Rasāil fi Faụāili al-A'māl wa al-Akhlāq. India: al-Maktabah al-Yahyawiyyah. 2011.

al-Nasa'i, Sunan al-Nasa'i bi Sharh al-Suyuti. Beirut: Dar al-Kutub al-'Ilmiyyah, T.th.

al-Qurthuby, Ibnu Rusyd. Sharh Bidāyatu al-Mujtahid wa Nihāyatu al-Maqāṣid, Kairo: Dār al-Salām. 1995.

al-Qushairi, Abu al-Husain Muslim ibn al-Hajjaj ibn Muslim. al-Jāmi' al-Shahih, Kitābu al-Imān juz 3. Riyadl: Dār al-Salām, tth.

al-Ṭabary, Abu Ja'far Muhammad ibn Jarir. Tafsìru al-Tabary, Jāmi'u al-Bayān 'an Ta’wïli Ayi al-Qur'ān juz 12, Kairo: Hajr. 2001.

al-Ṭayyār, Abdullah ibn Muhammad ibn Ahmad. al-Ṣalāt. Riyāḍ: Dār al-Waṭan.

al-Zuhayli, Wahbah. al-Fiqh al-Islami wa Adillatuhu. Beirut: Dar al-Fikr.1984.

Arifin, Zainal. Islam di Temboro Model Kepemimpinan dan Strategi Kebudayaan Jamaah Tabligh dalam Pembentukan Karakter. Yogyakarta: Program Studi MPI Fakultas Ilmu Tarbiyah dan Keguruan UIN Sunan Kalijaga Yogyakarta, 2017.

Al Hasyimi, Muhammad Luthvi, "Dampak Faham Keagamaan Jamaah Tabligh Terhadap Perubahan Sistem Pendidikan Di Pondok Pesantren Al Fatah Desa

Tribakti: Jurnal Pemikiran Keislaman

Volume 31, Nomor 2, Juli 2020 
Temboro Kecamatan Karas Kabupaten Magetan”. Jurnal Intelektual (2017) Vol. 7, No. 1: 100

Amalia, Azzahro. Struktur Sosial Keagamaan Jamaah Tabligh di desa Temboro Kecamatan Karas Kabupaten Magetan, Antropologi Fisip Universitas Airlangga Surabaya.

Aziz, Abdul. "Ighlāq al-Matājir li al-Ṣalāt Huda al-Naby wa Umarāi al-Muslimin," https://saaid.net/bahoth/122.htm

Faisal, Sanapiah. Penelitian Kualitatif, Dasar-dasar dan Aplikasi, Malang: YA3, 1990.

Ibn Kathir, Imāduddin Abi al-Fidā Ismāil. Tafsir Ibnu KathirJuz 10, Jizah: Muassasah Qurtubah. Tth.

Ibn Hanbal, Ahmad Ibn Muhammad. Al-Musnad Juz 11. Kairo: Dār al-Hadith. 1995.

Junaedi, Didi. Memahami Teks, Melahirkan Konteks: Menelisik Interpretasi Ideologis Jamaah Tabligh, Journal of Qur'ān and Hadith Studies (2017). Vol. 2, No. 1.

Malik ibn Anas, Al-Muwaththa' Riwāyatu Yahya ibn Yahya Juz 1, Beirut: Dār al-Gharb al-Islāmy.1997.

Mughniyah, Muhammad Jawad. Fiqih Lima Madzhab, Ja'fari, Hanafi, Maliki, Shafi'i, Hambali. Masykur, Afif Muhammad dan Idrus al-Kaff. Jakarta: Lentera. 2011.

Munir, Samsul. Pluralisme Madzhab Dakwah Jamaah Tabligh di Kampung Madinah, (Yogyakarta: Pustaka Ilmu, 2015).

Samuel, Hanneman. Peter Berger: Sebuah Pengantar Ringkas. Depok: Kepik, 2012.

Suparta, Mundzier. Perubahan Orientasi Pondok Pesantren Salafiyah terhadap Perilaku Keagamaan Masyarakat. Jakarta: Asta Buana Sejahtera, 2009.

Waluya, Bagja. Sosiologi: Menyelami Fenomena Sosial di Masyarakat, Bandung:Setia Purna Inves. 2004.

Prawiro, Abdurrahman Misno Bambang. Pesona Budaya Sunda: Etnografi Kampung Naga, Sleman: Budi Utama, 2019.

Qodir, Zuly. Islam Liberal, Varian-varian Liberalisme di Indonesia. Jogjakarta: Lkis, 2010

Yusuf, Moh. Gerakan Khurūj fĩ Sabīlillāh Sebagai Upaya Edukasi Membentuk Karakter Masyarakat: Studi Kasus Dakwah Jamaah Tabligh Temboro Magetan melalui Pendekatan Framing, Jurnal Kontemplasi, (Agustus, 2017) Vol. 05 No. 01.

Wikipedia Ensiklopedia Bebas, Budaya,"dalam https://id.wikipedia.org/wiki/Budaya

Zaki, Muhammad. Metode Pemahaman dan Pengamalan Hadits Jamaah Tabligh, Jurnal Pengembangan Masyarakat Islam (Agust us 2015) Vol. 8, No. 2. 